
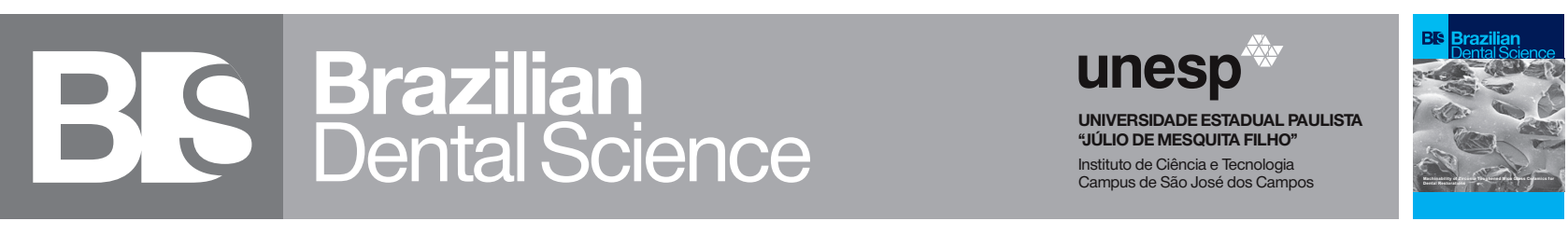

\title{
Evaluation of the influence of the impression technique, scanning direction and type of scanner on the accuracy of the final model
}

\author{
Avaliação da influência da técnica de impressão, direção de digitalização e tipo de scanner na precisão do modelo final
}

\begin{abstract}
Diogo Cabecinha VIEGAS ${ }^{1}$, João Tiago MOURÃO ${ }^{1}$, Joao Carlos ROQUE ${ }^{1}$, Hilton RIQUIERI ${ }^{3}$, João FERNANDES ${ }^{3}$, Fernando Vasconcelos ARROBAS $^{2}$, Pedro Jacy Santos DIAMANTINO ${ }^{2}$, Guilherme de Siqueira Ferreira Anzaloni SAAVEDRA ${ }^{1,2}$

1 - Department of Fixed Prosthodontics and Oral Rehabilitation, School of Dental Medicine, Lisbon University (FMDUL), Lisbon, Portugal.

2 - Department of Dental Materials and Prosthodontics, Institute of Science and Technology, São Paulo State University (Unesp), São José dos Campos, Brazil.

3 - School of Dental Medicine, Lisbon University (FMDUL), Lisbon, Portugal.
\end{abstract}

\begin{abstract}
Objective: The purpose of this study is to evaluate the influence of the type of scanner and scanning direction on the accuracy of the final cast. Material and Methods: A partial master cast was used as a reference. A total of 128 scans were obtained and divided into two groups: the conventional method and the digital method. The digital group was divided into three groups: TRIOS 3, Omnicam and CS 3600. Each of these groups was subdivided according to the scanning direction, and each scan was overlaid on the digital reference cast to measure the trueness and precision of the procedures. Results: The overall precision values for the type of impression were $59.89 \pm 13.08 \mu \mathrm{m}$ for conventional and 13.42 $\pm 4.28 \mu \mathrm{m}$ for digital; the values for trueness were $49.37 \pm 19.13 \mu \mathrm{m}$ for conventional and $53.53 \pm$ $4.97 \mu \mathrm{m}$ for digital; the scanning direction trueness values were $53.05 \pm 4.36 \mu \mathrm{m}$ for continuous and $54.03 \pm 5.52 \mu \mathrm{m}$ for segmented; and the precision values were $14.18 \pm 4.67 \mu \mathrm{m}$ for continuous and $12.67 \pm 3.75 \mu \mathrm{m}$ for segmented ( $>>0.05)$. For the scanner type, the trueness values were $50.06 \pm$ $2.65 \mu \mathrm{m}$ for Trios 3, $57.45 \pm 4.63 \mu \mathrm{m}$ for Omnicam, and $52.57 \pm 4.65 \mu \mathrm{m}$ for Carestream; and those for precision were $11.7 \pm 2.07 \mu \mathrm{m}$ for Trios $3,10.09$ $\pm 2.24 \mu \mathrm{m}$ for Omnicam, and $18.49 \pm 2.42 \mu \mathrm{m}$ for Carestream ( $\mathrm{p}<0.05)$. Conclusions: The digital impression method is the most favorable method regarding precision; in terms of trueness, there are no differences between the types of impressions.
\end{abstract}

\section{KEYWORDS}

Conventional impression; Intra oral impression; Accuracy; Trueness.

\section{RESUMO}

Objetivo: O objetivo deste estudo é avaliar a influência do tipo de técnica de moldagem, tipo de escâner intraoral e direção do escaneamento na precisão do modelo final. Material e Métodos: Um modelo parcial mestre foi usado como referência. Um total de 128 escaneamentos foi obtido e dividido em dois grupos: o método convencional ( $\mathrm{n}=32)$ e o método digital $(\mathrm{n}=96)$. O grupo digital foi dividido em três grupos: TRIOS $3(\mathrm{n}=32)$, Omnicam (n $=32)$ e CS $3600(n=32)$. Cada um desses grupos foi subdividido de acordo com a direção do escaneamento (n = 16), e cada escaneamento foi sobreposto ao modelo de referência digital para medir a veracidade e precisão dos procedimentos. Resultados: Os valores gerais de precisão para o tipo de impressão foram 59,89 $\pm 13,08 \mu \mathrm{m}$ para convencional e 13,42 $\pm 4,28 \mu \mathrm{m}$ para digital; os valores de veracidade foram $49,37 \pm 19,13 \mu \mathrm{m}$ para convencional e 53,53 $\pm 4,97 \mu \mathrm{m}$ para digital; os valores de veracidade para a direção de digitalização foram 53,05 \pm 4,36 $\mu \mathrm{m}$ para contínua e 54,03 $\pm 5,52 \mu \mathrm{m}$ para segmentada; e os valores de precisão foram 14,18 \pm 4,67 $\mu \mathrm{m}$ para contínua e $12,67 \pm 3,75 \mu \mathrm{m}$ para segmentada ( $>>0,05)$. Para o tipo de scanner, os valores de veracidade foram $50,06 \pm$ 2,65 $\mu \mathrm{m}$ para Trios $3,57,45 \pm 4,63 \mu \mathrm{m}$ para Omnicam e 52,57 $\pm 4,65 \mu \mathrm{m}$ para Carestream; e os de precisão foram 11,7 $\pm 2,07 \mu \mathrm{m}$ para Trios 3, 10,09 $\pm 2,24 \mu \mathrm{m}$ para Omnicam e 18,49 $\pm 2,42 \mu \mathrm{m}$ para Carestream (p $<0,05)$. Conclusões: $O$ método de moldagem digital é o método mais favorável em relação à precisão; em termos de veracidade, não há diferenças entre os tipos de impressão

\section{PALAVRAS-CHAVE}

Impressão convencional; Impressão intra oral; Precisão; Veracidade. 


\section{INTRODUCTION}

A $\mathrm{s}$ a result of technological developments, we are surrounded by resources that aim to make our daily activities more practical, comfortable and agile. This dynamism is present in dentistry, and currently, it is possible to perform major treatments with great agility and excellence while eliminating some stages and promoting advantages, such as greater comfort for the patient. [1]

Numerous dental procedures require a positive reproduction of teeth and other structures of interest, as well as of the antagonist arch [2,3] This stage needs to be carried out accurately to ensure good adaptation of prosthetic pieces to teeth, as well as greater longevity [4-7]

In this context, CAD/CAM (computeraided design/computer-aided manufacturing) has a central role, and it has gradually become part of dentist and technician routines. Inlays, onlays, crowns, veneers and fixed prostheses may be manufactured by means of computer-aided design (CAD) and milling (CAM) [8] Definitive restorations can thus be performed in a dental office or a lab that receives the data virtually [9]

The conventional models are obtained from a mold, defined as "a negative replica or reversed copy of the surface of an object; an impression of the teeth and adjacent structures for use in dentistry" [10]

During the impression stage, trays containing an elastomeric type of impression material are used [11,12] Some of the disadvantages of the conventional method have been eliminated, such as the tray selection stage, the distortion risk (molding, disinfecting, filling and shipment to the lab stages), and the patient's discomfort [13,14]

The CAD/CAM system allows the software to receive information directly from the patient's mouth through the use of an intraoral scanner for image capture. By means of data and algorithm calculations, the software generates an image on a computer screen, which results in a virtual and three-dimensional model [8]

Another great advantage of scanning is the reduction in the number of stages along with the patient's acceptance, since the procedure does not generate anxiety and does not interfere with natural breathing. [15,16] Moreover, the procedure is more comfortable, as well as easily and quickly performed, and the generation of a virtual model facilitates storage and allows the collected data to be manipulated $[15,17]$

To eliminate the conventional impression and the cast model, the end result of the digital impression should be as accurate as the conventional technique [11]

Therefore, considering these advantages that facilitate dentist and dental technician work, a comparison of the two techniques, bearing in mind that the conventional impression has been well-established due to length of usage and the achievement of satisfactory results, is an important tool for widening utilization based on the precision and accuracy of the acquired models [17-21]

The purpose of the present study was to evaluate the accuracy by means of trueness and precision considering the type of impression technique, scanning direction and their interaction.

\section{MATERIAL AND METHODS}

\section{Material}

In this study, a partial master model (with edentulous space in the element 25 region and dental preparations for elements 24 and 26) is used as a basis for comparison between analog and digital impression techniques (Figure 1A, B, C). The model is milled from polymer (Model Blank Bege 95H39, ZirkohnZahn $\mathrm{GmbH}$ ), and 120 models are obtained, which are divided into two large groups according to the data collection method (32 conventional models (CM) and 96 digital models (DM)). 


\begin{tabular}{ll}
\hline Viegas DC et al. & $\begin{array}{l}\text { Evaluation of the influence of the impression technique, scanning } \\
\text { direction and type of scanner on the accuracy of the final model }\end{array}$
\end{tabular}
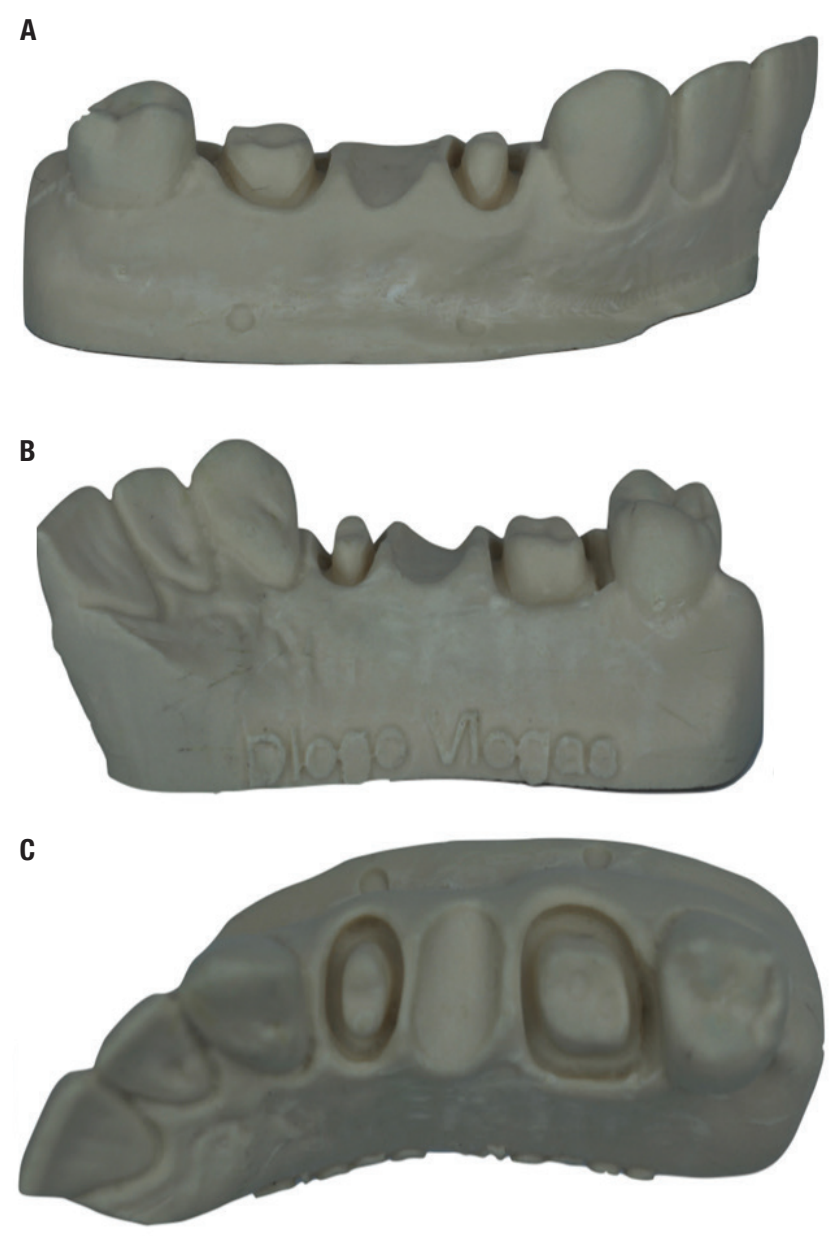

The pouring of the type IV plaster models (Fujirock, GC) followed the manufacturer recommendations.

The digital model group was subdivided into three minor groups according to the model used: TRIOS 3 (3Shape), CEREC Omnicam (Dentsply Sirona Systems), or CS3600 (Carestream) (Figures 4, 5, 6).

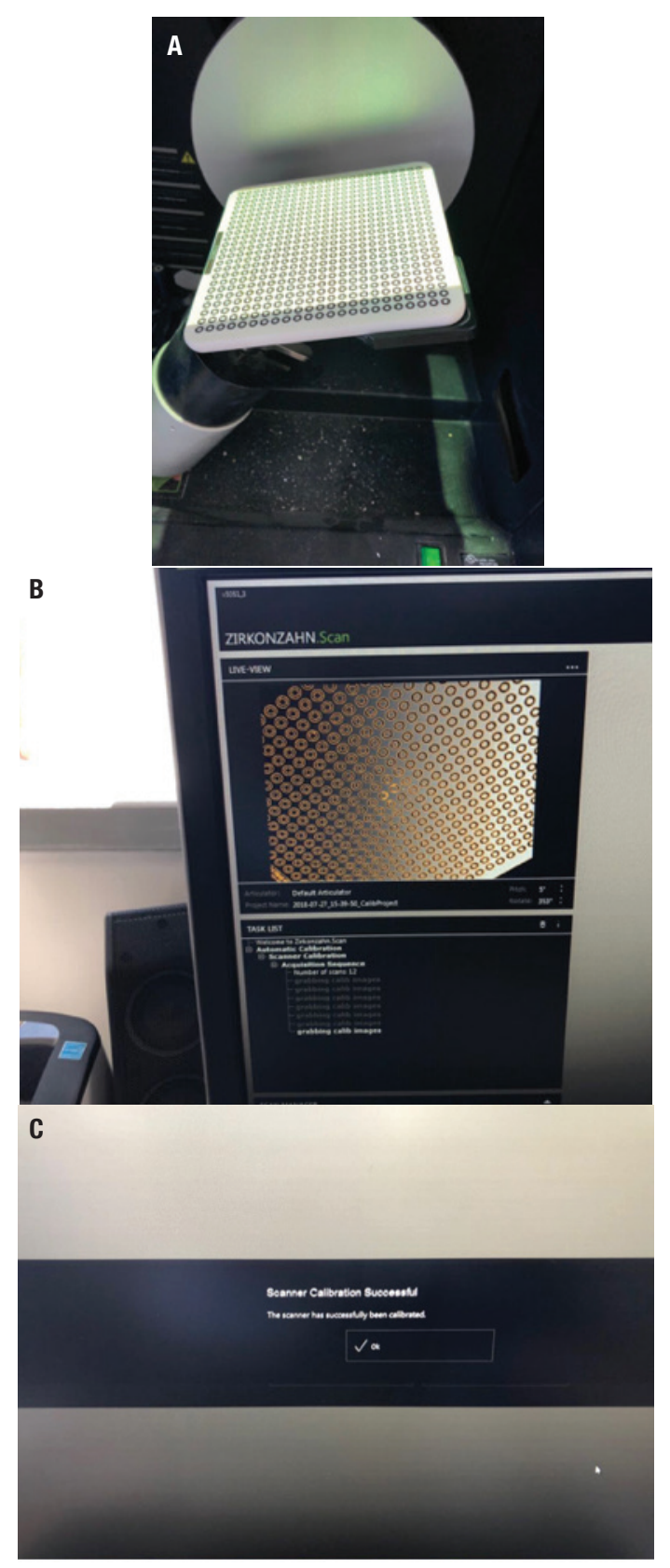

Figure 2A,B,C - Representative images of the calibration process of the ZirkohnZahn Scan software.

Figure 1A,B,C - Representative images of reference model (RM). Buccal, lingual and occlusal view.

\section{METHODS}

The calibration of the reference scanner was performed by applying a standard calibration plaque and selecting the option "Calibrate scan" on ZirkohnZahn Scan software (ZirkohnZahn $\mathrm{GmbH}$ ) according to the manufacturer recommendations (Figure 2A, B, C).

Forty-eight conventional impressions were poured into type IV plaster (Fujirock, GC) from digital impressions performed with individual trays through the two-step technique, with a polyvinylsiloxane material with a fluid and putty-like consistency (Virtual, Ivoclar Vivadent) and a polymerization period of 4,5 minutes (Figure 3A, B, C). 
A
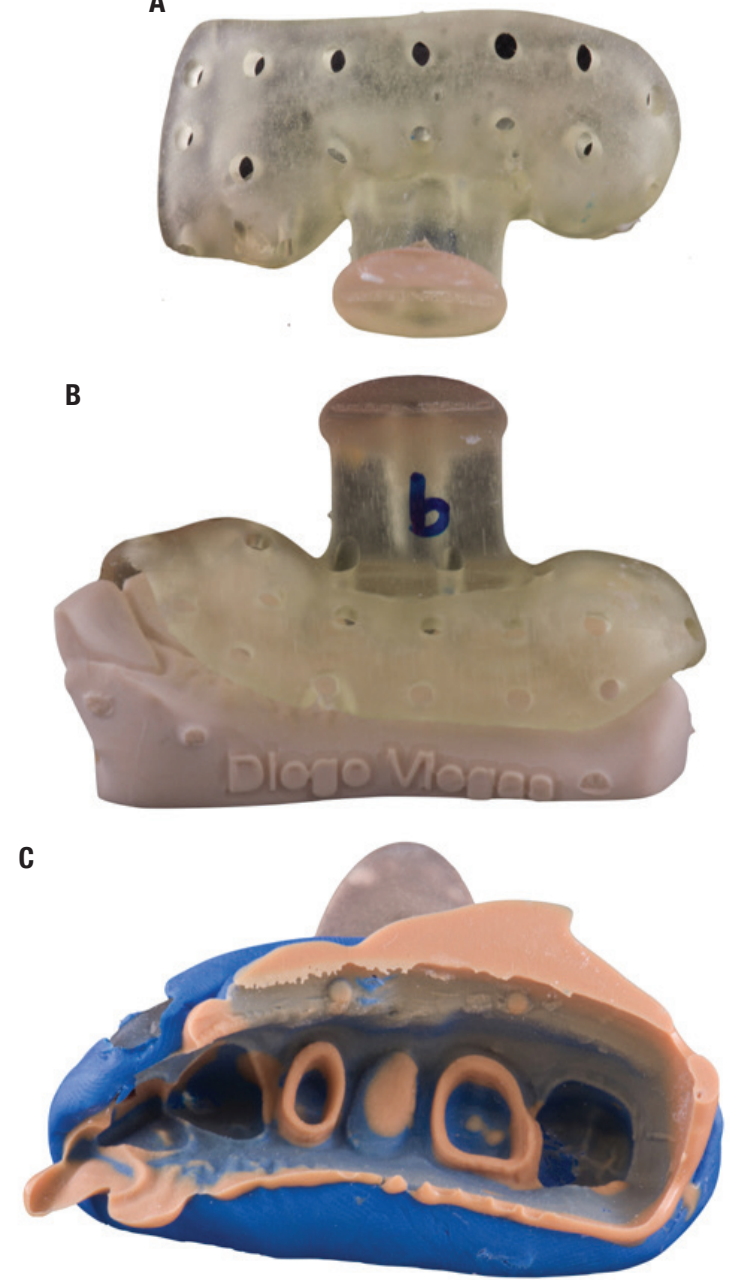

Figure 3 - A; Representative image of individual printed tray. Buccal view. B; Representative images of modified individual tray, positioned over the model. Lingual view. C; Putty and light polyvinylsiloxane impression of reference model. Occlusal view.

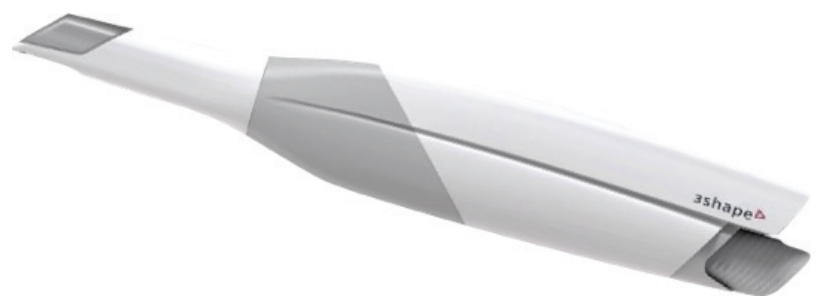

Figure 4 - Representative image of TRIOS 3 scanner.

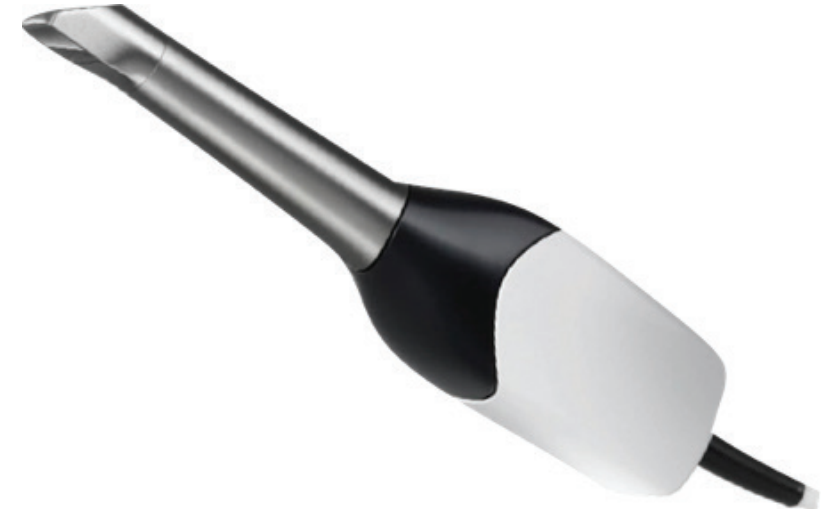

Figure 5 - Representative images of CEREC Omnicam.

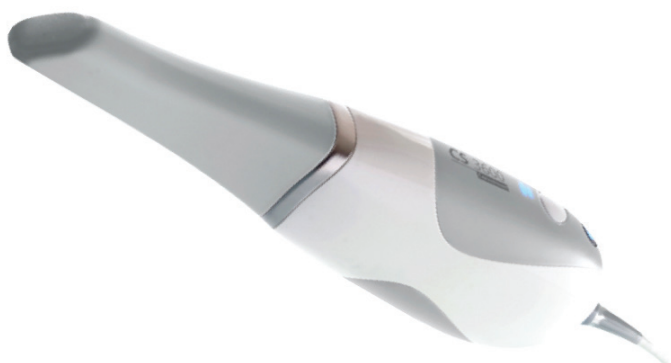

Figure 6 - Representative image of CS 3600.

The three groups were subdivided into two groups according to the scanning direction: segmented or continuous. The segmented method consisted of digitization from the occlusal surface of the most distal tooth (27), maintaining a focal distance of approximately $1 \mathrm{~cm}$ moving across the occlusal surface of the adjacent teeth to the element 21 incisor. Afterwards, the occlusion of the second molar (27) was revisited to reestablish a reference and allow the digitization of the vestibular surface in the anterior direction to the central incisor. Finally, the same procedure was repeated for the palatine surface. For the continuous method, maintaining the same focal distance, the process was initiated from the occlusal surface of 27 towards incisor 21 with short oscillatory movements in the buccal-lingual direction. From this point on, the scan was directed towards the vestibular surface in the distal direction to the vestibule of 27 and continuously towards the 
occlusion and palatine of 27. Afterwards, the scan progressed in the mesial direction to the palatine of 21, according to the schematic below (Figure 7A, B). The two methods were refined once by means of procedure repetition until complete closure of the mesh was achieved, finalized by the rendering process. [22]
A

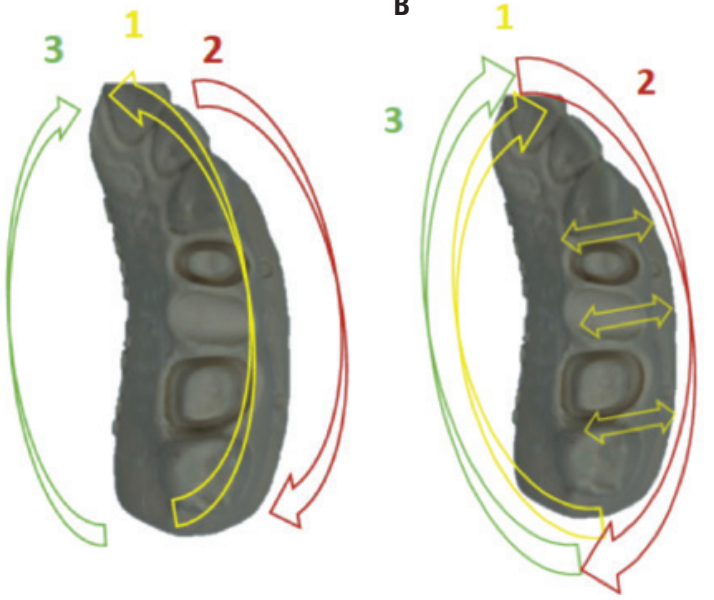

Figure 7 - A; Representation of continuos scanning direction and sequence of the reference model (RM). B; Representation of segmented scanning direction and sequence of the reference model $(\mathrm{RM})$.

All the scanners were calibrated according to the manufacturer recommendations prior to their use.

To evaluate and quantify the effect of the experience acquired by the operator on the accuracy of the digital reference model (DRM) obtained by the reference scanners (S600 Arti, ZirkohnZahn GmbH) compared to the obtained images, which were converted into .STL files (standard triangle language) by the three scanners in different steps $(n=16)$, an assessment was carried out between intergroups and intragroups with Geomagic Control X software (3D Systems).

The CM group models were scanned through the reference scanner (S600 ArtiZirkohnZahn $\mathrm{GmbH}$ ) and sent with the virtual models of the DM group to Geomagic Control $\mathrm{X}$ software (3D Systems) for intergroup and intragroup assessment of each technique (conventional vs. digital) as established by ISO 12836. [23]

To analyze these parameters, the collected data were converted into .STL files and sent to Geomagic Control X software (3D Systems). This software uses precise mathematical algorithms and objectively measures the possible volumetric variations in the whole model regarding the master model (Figure 8).

The data were analyzed using the MannWhitney U test $(a=.05)$ to assess whether the mean trueness and precision values of the two impression systems differed. Second, the MannWhitney test was used to assess whether the mean trueness and precision values of the two scanning directions differed. Third, ANOVA was used to assess whether the mean trueness and precision values of the three scanner systems differed.

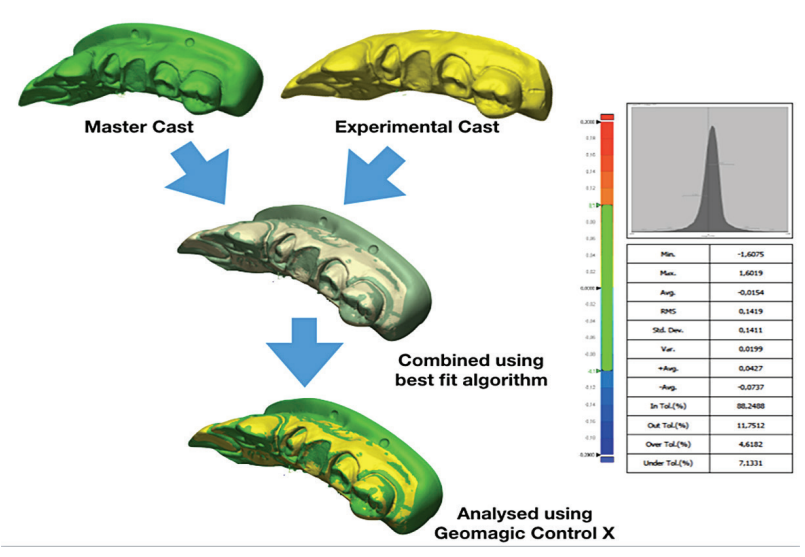

Figure 8 - Representation of the digital model analysis method with Geomagic Control X software.

\section{RESULTS}

In the present study, the results were obtained according to the following independent variables and their possible combinations: the impression models, scanning direction and type of scanner.

For the independent variable "impression methods" (digital and conventional), the mean values, standard deviation, standard error mean 
and confidence interval (95\%) regarding the trueness and precision are presented in Table I.

Table I - Descriptive statistics for trueness and precision regarding the impression method

\begin{tabular}{cccc} 
& & Trueness & Precision \\
\hline $\begin{array}{c}\text { Conventional } \\
(\mathbf{n = 3 2 )}\end{array}$ & Mean & 49.37 & 59.89 \\
& Standard deviation & 19.13 & 13.08 \\
& Standard error mean & 3.38 & 2.31 \\
& Confidence interval (95\%) & {$[42.48 ; 56.27]$} & {$[55.18 ; 64.61]$} \\
Digital & Mean & 53.53 & 13.42 \\
$(\mathbf{n = 9 6 )}$ & Standard deviation & 4.97 & 4.28 \\
& Standard error mean & 0.51 & 0.44 \\
& Confidence interval (95\%) & {$[52.53 ; 54.55]$} & {$[12.56 ; 14.29]$}
\end{tabular}

Regarding precision, the statistical test results show statistically significant differences $(p<0.05)$. In fact, we observe differences in terms of the mean and confidence interval of the two groups (Conventional: 59.89 [55.18; 64.61]; Digital: 13.42 [2,56; 14.29].

Regarding trueness, the statistical test results do not reveal statistically significant differences $(p>0.05)$. This means that the null hypothesis should not be rejected. The sample sizes of the two groups are different $(n=32$ and $\mathrm{n}=96$ ).

Regarding the independent variable "scanning direction" (continuous and segmented), the mean values, standard deviation, standard error mean and confidence interval (95\%) for trueness and precision are presented in Table II.

Table II - Descriptive statistics for trueness and precision regarding digitization direction

\begin{tabular}{cccc} 
& & Trueness & Precision \\
\hline $\begin{array}{c}\text { Continuous } \\
\text { (n= 48) }\end{array}$ & Mean & 53.05 & 14.18 \\
& Standard deviation & 4.36 & 4.67 \\
& Confidence interval (95\%) & {$[51.78 ; 54.31]$} & {$[12.82 ; 15.54]$} \\
\hline Segmented & Mean & 54.03 & 12.67 \\
(n=48) & Standard deviation & 5.52 & 3.75 \\
& Standard error mean & 0.79 & 0.54 \\
& Confidence interval (95\%) & {$[52.43 ; 55.63]$} & {$[11.58 ; 13.76]$}
\end{tabular}

There are no statistically significant differences between the two digitization techniques, and the effect size is small for both trueness and precision. As such, the null hypothesis should not be rejected.

Regarding the independent variable type of scanner (Trios 3, Omnicam and CS 3600), the mean values, standard deviation, standard mean error and confidence interval (95\%) for trueness and precision are presented in Table III.

Table III - Descriptive statistics for trueness and precision regarding the type of scanner

\begin{tabular}{|cccc|}
\hline & & Trueness & Precision \\
\hline & Mean & 50.6 & 11.7 \\
\hline Trios3 & Standard deviation & 2.65 & 2.07 \\
$\mathbf{( n = 3 2 )}$ & Standard error mean & 0.47 & 0.37 \\
& Confidence interval (95\%) & {$[49.65 ; 51.55]$} & {$[10.95 ; 12.45]$} \\
& Mean & 57.45 & 10.09 \\
\hline Omnicam & Standard deviation & 4.63 & 2.24 \\
$\mathbf{( n = 3 2 )}$ & Standard error mean & 0.82 & 0.39 \\
& Confidence interval (95\%) & {$[55.78 ; 59.12]$} & {$[9.28 ; 10.89]$} \\
& Mean & 52.57 & 18.49 \\
\hline CS3600 & Standard deviation & 4.65 & 2.42 \\
$\mathbf{( n = 3 2 )}$ & Standard error mean & 0.82 & 0.43 \\
& Confidence interval (95\%) & {$[50.89 ; 54.25]$} & {$[17.61 ; 19.36]$} \\
& & &
\end{tabular}

Table IV illustrates the results of the ANOVA one-way test for K-independent samples after confirmation of normality with the ShapiroWilk test with $\mathrm{p}>0.05$ in the three groups. It is possible to conclude that there are statistically significant differences in trueness $(\mathrm{p}<0.001)$ regarding the type of scanner.

Table IV - Multiple comparisons of the ANOVA test regarding trueness

\begin{tabular}{ccccc|}
$\begin{array}{c}\text { Type of } \\
\text { scanner }\end{array}$ & & $\begin{array}{c}\text { Mean } \\
\text { difference }\end{array}$ & Significance & Decision \\
\hline Trios3 & Omnicam & -0.0068 & $\mathrm{p}<0.001$ & Rejects $\mathrm{H}_{0}$ \\
& $\mathrm{CS} 3600$ & -0.0019 & $\mathrm{p}=0.104$ & Does not reject $\mathrm{H}_{0}$ \\
\hline \multirow{2}{*}{ Omnicam } & 3 Shape & 0.0068 & $\mathrm{p}<0.001$ & Rejects $\mathrm{H}_{0}$ \\
& $\mathrm{CS} 3600$ & 0.0048 & $\mathrm{p}<0.001$ & Rejects $\mathrm{H}_{0}$ \\
\hline \multirow{2}{*}{ CS3600 } & 3Shape & 0.0019 & $\mathrm{p}=0.104$ & Does not reject $\mathrm{H}_{0}$ \\
& Omnicam & -0.0048 & $\mathrm{p}<0.001$ & Rejects $\mathrm{H}_{0}$ \\
\hline
\end{tabular}


The multiple comparison analysis shows statistically significant differences between the Trios 3 and Omnicam scanners $((\mathrm{p}<0.001)$; mean difference: -0.0068$)$ and between CS 3600 and Omnicam $((\mathrm{p}<0.001)$; mean difference: $-0.0048)$

Table $\mathrm{V}$ illustrates the results of the Kruskal-Wallis test for K-independent samples, given that the null hypothesis of normality is rejected $(\mathrm{p}<0.001$ in two of the groups). The test result shows that there are statistically significant differences $(\mathrm{p}<0.001)$, which justifies conducting post hoc Games-Howell tests for multiple comparisons.

Table $\mathbf{V}$ - Hypothesis test for precision regarding the type of scanner

$\begin{array}{ccccc}\begin{array}{c}\text { Normal- } \\ \text { ity Test }\end{array} & \text { Decision } & \begin{array}{c}\text { Statistical } \\ \text { Test }\end{array} & \text { Decision } & \begin{array}{c}\text { Mean } \\ \text { Rank }\end{array} \\ \text { Trios } 3 & & & & \\ \text { SW(32)= } & & & & \text { 3Shape } \\ 0.793, & & & & 44.02 \\ p<0.001 & & & & \\ \text { Omnicam } & \text { The null } & \text { Kruskal-Wallis } & \text { There are } & \\ \text { Precision } & \text { SW(32)= hypothesis of } & \text { X2KW(2) } & \text { statistically } & \text { Omnicam } \\ 0.687, & \text { normality is } & =66.886, & \text { significant } & 22.55 \\ p<0.001 & \text { rejected } & p<0.001 & \text { differences } & \\ \text { CS } 3600 & & & & \text { Cares- } \\ \text { SW(32)= } & & & & \text { tream } \\ 0.982, p= & & & & 78.94 \\ 0.851 & & & & \end{array}$

A direct comparison between the Trios 3 and Omnicam scanners presents statistically significant differences in precision. Omnicam is more precise (mean rank: 21.83 and $\mathrm{p}<0.001$ ), and the effect size is large $(\mathrm{r}=-0.57)$ (Table VI).

Table VI - Hypothesis test for precision regarding the type of scanner

\begin{tabular}{|c|c|c|c|c|}
\hline & $\begin{array}{c}\text { Statistical } \\
\text { Test }\end{array}$ & Decision & Mean Ranks & $\begin{array}{c}\text { Effect Size } \\
r=Z /(\sqrt{ })\end{array}$ \\
\hline Precision & $\begin{array}{c}\text { Mann-Whitney } \\
\text { U= } 170.50 \\
p<0.001\end{array}$ & $\begin{array}{l}\text { There are } \\
\text { statistically } \\
\text { significant } \\
\text { differences }\end{array}$ & $\begin{array}{c}\text { 3Shape } \\
43.17 \\
\text { Omnicam } \\
21.83\end{array}$ & $r=-0.57$ \\
\hline
\end{tabular}

A direct comparison between the Trios 3 and CS 3600 scanners evinces statistically significant differences in precision. Trios 3 is more precise (mean rank: 17.34 and $\mathrm{p}<0.001$ ) (Table VII).

Table VII - Hypothesis test for precision of Trios 3 vs Carestream

\begin{tabular}{|c|c|c|c|c|}
\hline & $\begin{array}{c}\text { Statistical } \\
\text { Test }\end{array}$ & Decision & Mean Ranks & $\begin{array}{l}\text { Effect Size } \\
r=Z /(\sqrt{ } n)\end{array}$ \\
\hline Precision & $\begin{array}{c}\text { Mann-Whitney } \\
\mathrm{U}=23.0 \\
\mathrm{p}<0.001\end{array}$ & $\begin{array}{l}\text { There are } \\
\text { statistically } \\
\text { significant } \\
\text { differences }\end{array}$ & $\begin{array}{c}\text { Omnicam } \\
17.22 \\
\text { Carestream } \\
47.78\end{array}$ & $r=-0.82$ \\
\hline
\end{tabular}

A direct comparison between these two scanners indicates a statistically significant difference in precision. Omnicam is more precise (mean rank: 17.22 and $\mathrm{p}<0.001$ ) (Table VIII).

Table VIII - Hypothesis test for precision of Omnicam vs Carestream

\begin{tabular}{|c|c|c|c|c|}
\hline & $\begin{array}{c}\text { Statistical } \\
\text { Test }\end{array}$ & Decision & Mean Ranks & $\begin{array}{l}\text { Effect Size } \\
r=Z /(\sqrt{ } n)\end{array}$ \\
\hline Precision & $\begin{array}{c}\text { Mann-Whitney } \\
U=23.0 \\
p<0.001\end{array}$ & $\begin{array}{l}\text { There are } \\
\text { statistically } \\
\text { significant } \\
\text { differences }\end{array}$ & $\begin{array}{c}\text { Omnicam } \\
17.22 \\
\text { Carestream } \\
47.78\end{array}$ & $r=-0.82$ \\
\hline
\end{tabular}

In Table IX, the mean values, standard deviation, standard error mean and confidence interval (95\%) for trueness and precision are presented for the combination of the independent variables type of scanner and digitization direction. 
Table IX - Descriptive statistics for trueness and precision regarding variable interactions and digitization direction

\begin{tabular}{|c|c|c|c|}
\hline & & Trueness & Precision \\
\hline \multirow{4}{*}{$\begin{array}{l}\text { Trios } 3 \text { conti- } \\
\text { nuous } \\
(n=16)\end{array}$} & Mean & 51.93 & 12.94 \\
\hline & Standard deviation & 2.61 & 2.26 \\
\hline & Standard error mean & 0.65 & 0.57 \\
\hline & Confidence interval (95\%) & {$[50.54 ; 53.31]$} & [11.74; 14.15] \\
\hline \multirow{4}{*}{$\begin{array}{c}\text { Trios } 3 \text { seg- } \\
\text { mented } \\
(n=16)\end{array}$} & Mean & 49.28 & 10.46 \\
\hline & Standard deviation & 1.98 & 0.68 \\
\hline & Standard error mean & 0.49 & 0.17 \\
\hline & Confidence interval (95\%) & {$[48.22 ; 50.33]$} & [10.09; 10.82] \\
\hline \multirow{4}{*}{$\begin{array}{c}\text { Omnicam_conti- } \\
\text { nuous } \\
(n=16)\end{array}$} & Mean & 56.26 & 9.6 \\
\hline & Standard deviation & 3.98 & 0.96 \\
\hline & Standard error mean & 0.99 & 0.24 \\
\hline & Confidence interval (95\%) & [54.13;58.38] & [9.12; 10.1] \\
\hline \multirow{4}{*}{$\begin{array}{c}\text { Omnicam_Seg- } \\
\text { mented } \\
(n=16)\end{array}$} & Mean & 58.64 & 10.55 \\
\hline & Standard deviation & 5.04 & 3.01 \\
\hline & Standard error of the mean & 1.26 & 0.75 \\
\hline & Confidence interval (95\%) & {$[55.95 ; 61.32]$} & {$[8.94 ; 12.15]$} \\
\hline \multirow{4}{*}{$\begin{array}{c}\text { CS3600_conti- } \\
\text { nuous } \\
(n=16)\end{array}$} & Mean & 50.96 & 19.03 \\
\hline & Standard deviation & 4.47 & 1.74 \\
\hline & Standard error of the mean & 1.12 & 0.44 \\
\hline & Confidence interval (95\%) & {$[48.58 ; 53.34]$} & {$[19.03 ; 20.89]$} \\
\hline \multirow{4}{*}{$\begin{array}{c}\text { CS3600 seg- } \\
\text { mented } \\
(n=16)\end{array}$} & Mean & 54.18 & 17.01 \\
\hline & Standard deviation & 4.39 & 2.11 \\
\hline & Standard error mean & 1.09 & 0.53 \\
\hline & Confidence interval (95\%) & {$[51.84 ; 56.52]$} & [15.88; 18.14] \\
\hline
\end{tabular}

To assess the influence of the technique on trueness regarding type of scanner, the ANOVA two-way test is conducted, since normality and equality variance are assumed for all groups.

The table analysis shows that the scanning direction has an influence on the type of scanner result.

When evaluating the multiple comparisons table (Table $\mathrm{X}$ ), it is identified that the stratification by type of scanner is not influenced by the scanning technique, which means there are no statistically significant differences between the trueness of each type of scanner $(p>0.05)$ when the conventional and segmented techniques are applied. The null hypothesis is retained when comparing Trios 3 with the continuous technique to Trios
3 with the segmented technique $(\mathrm{p}=0.395)$, when comparing CS 3600 with the continuous technique to CS 3600 with the segmented technique $(p=0.189)$, and when comparing Omnicam with the continuous technique to Omnicam with the segmented technique $(\mathrm{p}=$ $0.517)$ regarding trueness.

Table X - Multiple comparisons related to interaction between digitization direction and type of scanner regarding trueness

\begin{tabular}{|c|c|c|c|c|c|}
\hline \multirow{2}{*}{$\begin{array}{l}\text { (I) variable } \\
\text { combined }\end{array}$} & \multirow{2}{*}{$\begin{array}{l}\text { (J) variable_com- } \\
\text { bined }\end{array}$} & \multirow{2}{*}{$\begin{array}{c}\text { Mean } \\
\text { Difference } \\
(\text { I-J) }\end{array}$} & \multirow{2}{*}{$\begin{array}{l}\text { Std. } \\
\text { Error }\end{array}$} & \multirow[t]{2}{*}{ Sig. } & $\begin{array}{l}95 \% \text { Con- } \\
\text { fidence } \\
\text { Interval }\end{array}$ \\
\hline & & & & & $\begin{array}{l}\text { Lower } \\
\text { Bound }\end{array}$ \\
\hline \multirow{5}{*}{$\begin{array}{c}\text { Trios } 3 \text { conti- } \\
\text { nuous }\end{array}$} & trios 3 segmented & .002650 & .001378 & .596 & -.00204 \\
\hline & omnicam_continuous & -.004330 & .001378 & .090 & -.00902 \\
\hline & omnicam_segmented & $-.006713^{\star}$ & .001378 & .001 & -.01140 \\
\hline & cs 3600 continuous & .000968 & .001378 & .992 & -.00372 \\
\hline & cs 3600 _segmented & -.002256 & .001378 & .749 & -.00695 \\
\hline \multirow{5}{*}{$\begin{array}{l}\text { Trios3 seg- } \\
\text { mented }\end{array}$} & trios 3 continuous & -.002650 & .001378 & .596 & -.00734 \\
\hline & omnicam_continuous & $-.006980^{\star}$ & .001378 & .000 & -.01167 \\
\hline & omnicam_segmented & $-.009363^{\star}$ & .001378 & .000 & -.01405 \\
\hline & cs 3600 continuous & -.001682 & .001378 & .913 & -.00637 \\
\hline & cs 3600 segmented & $-.004906^{\star}$ & .001378 & .034 & -.00960 \\
\hline \multirow{5}{*}{$\begin{array}{c}\text { Omnicam_con- } \\
\text { tinuous }\end{array}$} & trios 3 continuous & .004330 & .001378 & .090 & -.00036 \\
\hline & trios 3 segmented & $.006980^{\star}$ & .001378 & .000 & .00229 \\
\hline & omnicam_segmented & -.002383 & .001378 & .702 & -.00707 \\
\hline & cs 3600 continuous & $.005298^{\star}$ & .001378 & .016 & .00061 \\
\hline & cs 3600 _segmented & .002074 & .001378 & .810 & -.00262 \\
\hline \multirow{5}{*}{$\begin{array}{l}\text { Omnicam_seg- } \\
\text { mented }\end{array}$} & trios 3 continuous & $.006713^{*}$ & .001378 & .001 & .00202 \\
\hline & trios 3 segmented & $.009363^{\star}$ & .001378 & .000 & .00467 \\
\hline & omnicam_continuous & .002383 & .001378 & .702 & -.00231 \\
\hline & $\operatorname{cs} 3600$ & $.007681^{\star}$ & .001378 & .000 & .00299 \\
\hline & cs 3600 segmented & .004456 & .001378 & .074 & -.00023 \\
\hline \multirow{5}{*}{$\begin{array}{c}\text { CS3600_conti- } \\
\text { nuous }\end{array}$} & trios 3 continuous & -.000968 & .001378 & .992 & -.00566 \\
\hline & trios 3 segmented & .001682 & .001378 & .913 & -.00301 \\
\hline & omnicam_continuous & $-.005298^{\star}$ & .001378 & .016 & -.00999 \\
\hline & omnicam_segmented & $-.007681^{\star}$ & .001378 & .000 & -.01237 \\
\hline & cs 3600 segmented & -.003224 & .001378 & .369 & -.00791 \\
\hline \multirow{5}{*}{$\begin{array}{l}\text { CS3600 seg- } \\
\text { mented }\end{array}$} & trios 3 continuous & .002256 & .001378 & .749 & -.00243 \\
\hline & trios 3 segmented & $.004906^{*}$ & .001378 & .034 & .00022 \\
\hline & omnicam_continuous & -.002074 & .001378 & .810 & -.00676 \\
\hline & omnicam_segmented & -.004456 & .001378 & .074 & -.00915 \\
\hline & cs 3600 continuous & .003224 & .001378 & .369 & -.00147 \\
\hline
\end{tabular}


Therefore, the multiple comparisons between different scanning directions and different types of scanners (e.g., Trios 3 with continuous technique vs Omnicam with segmented technique) are not relevant enough to report since the sensitive factor appears to be the type of scanner. The fact that these comparisons are statistically significant (although devoid of practical relevance) justifies the statistically significant result of the two-way ANOVA test $(\mathrm{p}=0.007)$ initially conducted.

When evaluating precision regarding the technique used with the Trios 3 scanner, statistically significant differences are identified $(\mathrm{p}<0.001)$, as well as a large effect size in favor of the segmented technique, which suggests that for this type of scanner, the segmented technique is more favorable (mean rank: 9.75) (Table XI).

Table XI - Hypothesis test for precision of Trios 3 continuous vs segmented

$\begin{array}{ccccc} & \text { Statistical } & \text { Decision } & \text { Mean Ranks } & \text { Effect Size } \\ & \text { Test } & \text { De } /(\sqrt{ } \mathbf{n})\end{array}$

When evaluating precision regarding the technique used with the Omnicam scanner, no statistically significant differences are detected $(p=0.955)$, and a small effect size is observed, which suggests that for this type of scanner, the technique is irrelevant (mean rank - continuous: 16.59, segmented: 16.41) (Table XII).

Table XII - Hypothesis test for precision of Omnicam continuous vs segmented

\begin{tabular}{|c|c|c|c|c|}
\hline & $\begin{array}{c}\text { Statistical } \\
\text { Test }\end{array}$ & Decision & Mean Ranks & $\begin{array}{l}\text { Effect Size } \\
r=Z /(\sqrt{ } n)\end{array}$ \\
\hline Precision & $\begin{array}{c}\text { Mann-Whitney } \\
U=126.500 \\
p=0.955\end{array}$ & $\begin{array}{l}\text { There are no } \\
\text { statistically } \\
\text { significant } \\
\text { differences }\end{array}$ & $\begin{array}{c}\text { Continuous } \\
16.59 \\
\text { Segmented } \\
16.41\end{array}$ & $r=-0.17$ \\
\hline
\end{tabular}

When evaluating precision regarding the technique utilized with the CS 3600 scanner, statistically significant differences, as well as a large effect size in favor of the segmented technique, are identified $(\mathrm{p}<0.001)$, which suggests that for this type of scanner, the segmented technique is more favorable (mean rank: 10.63) for obtaining more precise models. (segmented: mean - 0.017 and IC95\% [0.016; 0.018] and continuous: mean- 0.019 and IC95\% [0.019; 0.021]) (Table XIII).

Table XIII - Hypothesis test for precision of Carestream ${ }^{\circledR}$ continuous vs segmented

\begin{tabular}{|c|c|c|c|c|}
\hline & $\begin{array}{c}\text { Statistical } \\
\text { Test }\end{array}$ & Decision & Mean Ranks & $\begin{array}{l}\text { Effect Size } \\
r=Z /(\sqrt{ } n)\end{array}$ \\
\hline Precision & $\begin{array}{c}\text { Mann-Whitney } \\
\mathrm{U}=34.000 \\
\mathrm{p}<0.001\end{array}$ & $\begin{array}{l}\text { There are no } \\
\text { statistically } \\
\text { significant } \\
\text { differences }\end{array}$ & $\begin{array}{c}\text { Continuous } \\
22.38 \\
\text { Segmented } \\
10.63\end{array}$ & $r=-0.63$ \\
\hline
\end{tabular}

\section{DISCUSSION}

The limitations of elastomeric materials and impression techniques have been widely studied to justify the need for renewal of materials, as well as impression techniques [22] The sensitivity of the technique, the patient's discomfort, dimensional changes through contraction after polymerization, distortion of the tray, plaster expansion and changes caused by disinfecting agents may be seen as weak points [11,23-27] Nevertheless, this combination has been successful for a long period of time [28]

Two events are considered to have led to an increase in the use of digital technology in dentistry: curiosity towards novelty and the increase in digital technology use in basic training provided by universities [9]

Moreover, the clinical implications of the use of intraoral scanners are very relevant. Intraoral scanners show extreme trueness and precision. However, each scanner has strong and weak points that should be considered, since no equipment has yet proven to have the best precision, trueness and speed combination [19] 
The main characteristic of a scanner should be the accuracy defined by the conjunction or sum of two factors: precision and trueness [2937]

The replacement of both the conventional impression and the cast model would be justifiable if the final quality of the digital impression meets, at minimum, the same qualitative level of accuracy as that of conventional techniques [11]

A review of the scanning of both singleunit restorations and multiple restorations with up to 4-5 elements is favorably comparable to the conventional method regarding precision. For single-unit teeth impressions, several studies have considered that the digital method is similar to the conventional method of impression with polyvinylsiloxane and polyether [33,38-40] Additionally, as the extension of the digitization area increases, directly proportional distortion may ensue $[4,9,41-44]$

Many studies concur with our results, wherein the digital method surpasses the precision results regarding conventional methods [1,13,41,42,45-47]

Regarding the trueness of the impression method (conventional and digital), the results present no statistically significant differences ( $p>0.05$ ), and the effect size is moderate (0.298). This means that the null hypothesis should not be rejected. However, there are some limitations related to these results that should be considered. For one, the sample sizes of the groups are different $(C M n=32$ and $D M n=96)$.

In contrast with our results, one study found higher trueness in models generated by scanning of conventional impressions with polyether for up to 3-4 elements [48]. It should be noted that, in our study, polyvinylsiloxane was used.

In this study, the scanning of single-unit restorations is favorably comparable to the conventional method regarding trueness. For impressions on single-unit teeth, several studies stated that the digital method was similar to the conventional method of impressions with polyvinylsiloxane and polyether $[38,39,48]$.

Other authors have observed differences in the numerical values for trueness as the width and extension of the digitized dental arch increased. Thus, it is concluded that the larger the extension is, the lower the trueness $[4,9,49]$.

It is important to note that when the learning curve is complete, the digital method possesses the advantage of involving fewer stages, which makes the process simpler, thus reducing the risk of error. [15,16] In complex cases, this makes the process easier, diminishing the risk of repetition. If necessary, repetition does not become a problem since the digital method enables the reproduction of the defective part alone $[31,35]$.

Another relevant issue is the patients' preference for this technique over the conventional technique [14].

Moreover, because the data are digital, virtual models can be obtained, which facilitates the storage and manipulation of the collected data $[15,17]$.

Therefore, considering the advantages that facilitate dentist and dental technician routines, a comparison between the two techniques, while bearing in mind that conventional impressions have been established through length of usage and achievement of satisfactory results, is an important tool for increasing utilization based on the precision and accuracy of the obtained models [17-21].

Regarding the digitization direction, continuous or segmented, no statistically significant differences are found, and the effect size is small. As such, the null hypothesis should be retained and, therefore, not rejected.

However, as far as the digitization direction variable combined with the type of scanner is concerned, it is observable that 
the mean values do not present a statistically significant difference, thus confirming the null hypothesis. Another study concluded that there was no influence from the scanning direction on the precision of 3D images and that all the results were clinically acceptable. The type of model used by these authors could justify this fact [15].

On the other hand, there is a study that corroborates the results of the present study. The authors evaluated four different types of digitization strategies and obtained statistically equal results for the three evaluated scanners. Only one scanner (iTero) showed an influence from the digitization direction on the results [50].

The Trios 3 and Omnicam scanners produced digital images that were compared to each other; the data were subjected to the Kruskal-Wallis test, executed for independent samples (Table IX). Since the statistical variation was representative, the post hoc test was then carried out for multiple comparisons, which confirmed the superiority of the Omnicam equipment. Despite these differences between scanners, it should be stated that, within the scope of a clinic, they do not have an effect on the results of treatment.

According to the test "hypothesis for precision: Trios 3 versus CS 3600" (Table X), there are no statistically significant variations between the obtained models, notwithstanding the fact that the image capture conditions with the intraoral scanner remain unaltered. In this context, the Trios 3 scanner presents greater trueness than the CS 3600 scanner.

In the comparative test between Omnicam and CS 3600 (Table XI), regarding "precision", Omnicam is superior, although these differences are centered in the statistical field. A low clinical relevance is observed regarding the adaptation of restorations given the high sensitivity of the standard deviation tests.
On the other hand, no similarities are found in comparison with previous studies regarding trueness. In other research, partial and total arch models that were obtained by several scanner brands and by the traditional impression technique were compared, and it was observed that the digital precision values were superior to those of the conventional technique in small areas, which is inversely proportional to the conclusions for larger area models [41].

In contrast, a study that used five scanner models as alternatives to impression materials for rehabilitation with implants, total and partial, demonstrated that the distortions found regarding the stability and longevity of the treatments were not relevant as long as the selection of a specific scanner was in accordance with its clinical indications [33].

\section{CONCLUSIONS}

The digital impression method was the most favorable method regarding precision. In terms of trueness, there were no differences. The scanning direction did not influence the accuracy of the final casts. Trios 3 was shown to be the most accurate scanner.

\section{Acknowledgments}

The authors are grateful to Guilherme Saavedra for content contributions, João Tiago Mourão for their critical review of the manuscript and the João Fernandes and Fernando Arrobas for support during the development and writing of these manuscript.

\section{Funding}

The author(s) received no specific funding for this work.

\section{Conflict of interest}

The authors have no proprietary, financial, or other personal interest of any nature or kind in any product, service, and/or company that is presented in this article. 


\section{REFERENCES}

1. Sim JY,Jang Y, Kim WC, Kim HY, Lee DH, Kim JH. Comparing the accuracy (trueness and precision) of models of fixed dental prostheses fabricated by digital and conventional workflows. J Prosthodont Res. 2019 Jan;63(1):25-30. doi:10.1016/j.jpor.2018.02.002

2. Brawek PK, WolfartS, Endres L, Kirsten A, ReichS. The clinical accuracy of single crowns exclusively fabricated by digital workflow-the comparison of two systems. Clin Oral Investig. 2013 Dec;17(9):2119-25. doi:101007/s00784013-0923-5.

3. Craddock MR, WindhornRJ (2011) Is the US Army Dental Corpsready for the digital impression? US Army Med Dep J. Jan-Mar:38-41

4. Ender A, Mehl A. Accuracy of complete-arch dental impressions: a new method of measuring trueness and precision. J Prosthet Dent. 2013 Feb;109(2):121-128. doi:10.1016/S0022-3913(13)60028-1.

5. Perakis N, Belser U, Magne P. Final impressions: a review of material properties and description of a current technique. Int J Periodontics Restorative Dent. 2004;24:109-17.

6. Persson A, Odén A, Andersson M, Sand-borgh-Englund G. Digitization of simulated clinical dental impressions: virtual three-dimensional analysis of exactness. Dent Mater. 2009;25:929-36. doi:10.1016/j.dental.2009.01.100.

7. Wettstein F, Sailer I, Roos M, Hämmerle C. Clinical study of the internal gaps of zirconia and metal frameworks for fixed partial dentures. Eur $\mathrm{J}$ Oral Sci. 2008;116:272-93. doi:10.1111/j.1600-0722.2008.00527.x

8. Ahlholm P,SipiläK, Vallittu P, Jakonen M, Kotiranta U. Digital Versus Conventional Impressions in Fixed Prosthodontics: A Review. JProsthodont. 2018 Jan;27(1):35-41. doi:10.1111/jopr.12527.

9. Ender A, Mehl A. In-vitro evaluation of the accuracy of conventional and digital methods of obtaining full-arch dental impressions. Quintessence Int. 2015 Jan; 46(1):9-17.doi:10.3290/j.qi.a32244.

10. The glossary of prosthodontic terms. J Prosthet Dent 2017,177(55):1-105. doi: 10.1016/j.prosdent.2016.12.001.

11. Christensen GJ:Impressions are changing: deciding on conventional, digital or digital plus in-office milling. J Am Dent Assoc. 2009;140:1301-4. doi:10.14219/ jada.archive.2009.0054

12. Gjelvold B, Chrcanovic BR, Korduner EK, Collin-BagewitzI, Kisch J. Intraoral Digital Impression Technique Compared to Conventional Impression Technique. A Randomized Clinical Trial. J Prosthodont. 2016 Jun;25(4):282-7. doi: 10.1111/ jopr.12410.

13. Marghalani A, Weber HP,Finkelman M, Kudara Y, EI Rafie K, Papaspyridakos P.Digital versus conventional implant impressions for partially edentulous arches: An evaluation of accuracy.J ProsthetDent. 2018 Apr;119(4):574-9. doi: 10.1016/jprosdent.2017.07.002.

14. Yuzbasioglu E1, KurtH, Turunc R, Bilir H. Comparison of digital and conventional impression techniques: evaluation of patients' perception, treatment comfort, effectiveness and clinical outcomes. BMC Oral Health. 2014 Jan;30(14):10. doi: 10.1186/1472-6831-14-10.

15. Anh JW, Park JM, Chun YS, Kim M, Kim M. A comparison of the precision of three-dimensional images acquired by 2 digital intraoral s: effects of tooth irregularity and scanning direction. Korean J Orthod. 2016 Jan;46(1):3-12. doi: 10.4041/kjod.2016.46.1.3.

16. Watanabe-Kanno GA, Abrão J, Miasiro Junior H, Sánchez-Ayala A, Lagravère MO. Reproducibility, reliability and validity of measurements obtained from Cecile3 digital models. Braz Oral Res. 2009;23:288-95. doi: 10.1590/s1806-8324200900030011
17. Al Mortadi N, Eggbeer D, Lewis J, Williams RJ. CAD/CAM applications in the manufacture of dental appliances. Am J Orthod Dentofacial Orthop. 2012; 142:727-33. doi: 10.10.2016/j.ajodo.2012.04.023.

18. Lim JH, Park JM, Kim M, Heo SJ, Myung JY. Comparison of digital intraoral reproducibility and image trueness considering repetitive experience.J Prosthet Dent. 2018 Feb;119(2):225-32. do: 10.1016/.jprosdent.2017.05.002.

19. Renne W, et al. Evaluation of the accuracy of 7 digital $\mathrm{s}$ : An in vitro analysis based on 3-dimensional comparisons. J ProsthetDent. 2017 Jul;:118(1):36-42. doi:10.1016/.jprosdent.2016.09.024.

20. Chun J, Tahk JH, Chun Y,Park J, Kim M. Analysis on the accuracy of intraoral scanners: The effects of mandibular anterior interdental space. Appl Sci. 2017,7(7):719. doi:10.3390/app7070719.

21. Sottomayor PM, Moscardó AP,Camps I. Relationship between resolution and accuracy of four intraoral s in complete arch impressions. J Clin Exp Dent. 2018;10(4):361-6. doi:10.4317/jced.54670.

22. Carrotte P,Winstanley R, Green J.A study of the quality of impressions for anterior crowns received at a commercial laboratory. Br Dent J. 1993;174:23540. doi: 10.1038/sj.bdj.4808162.

23. Millstein P.Determining the accuracy of gypsum casts made from type IV dental stone. J Oral Rehabi. 1992;19:239-43. doi:10.1111//.1365-28421992. tb01098.x.

24. SametN, Shohat M, Livny A, Weiss E. A clinical evaluation of fixed partial denture impressions. J Prosthet Dent. 2005;94:112-7. doi:10.1016/j. prosdent.2005.05.002.

25. Amin WM, Al-Ali MH, Al Tarawneh SK, Taha ST, Saleh MW,Ereifij N. The effects of disinfectants on dimensional accuracy and surface quality of impression materials and gypsum casts. J Clin Med Res. 2009;:181-9. doi:10.4021/ jocmr2009.04.1235.

26. Chen C,Anusavice AJ. Impression materials: Phillips' science of dental materials. 12th ed. St. Louis: Elsevier;2012:239-42.

27. Revised American Dental Association Specification No. 19 for non-aqueous, elastomeric dental impression materials. J Amer Dent Assoc. 1977;94:733-41

28. Ragain JC, Grosko ML, Raj M, Ryan TN, Johnston WM. Detail reproduction, contact angles, and die hardness of elastomeric impression and gypsum die material combinations. Int J Prosthodont. 2000 May-Jun;13(3):214-20.

29. International Organization for Standardization. Accuracy (trueness and precision) of measurement methods and results e Part 1: General principles and definitions (IS0 5725e1:1994). Berlin: Beuth Verlag GmbH; 1997.

30. Ting-Shu S, Jian S. Intraoral Digital Impression Technique: A Review. J Prosthodont. 2015;24(4):313-21. doi: 10.1111/jopr.12218.

31. Zimmermann M, Mehl A, Mörmann WH, Reich S. Intraoral scanning systems a current overview. Int J ComputDent. 2015;18(2):101-29.

32. Martin CB, Chalmers EV,Mclntyre GT, Cochrane H, Mossey PA Orthodontic scanners: what's available? J Orthod. 2015;42(2):136-43. doi: 10.1179/1465313315Y.0000000001.

33. Imburgia M, Logozzo S, Hauschild U, Veronesi G, Mangano C, Mangano FG. Accuracy of four intraoral scanners in oral implantology: a comparative in vitro study.BMC Oral Health. 2017;17(1):92. doi: 10.1186/s12903-017-0383-4.

34. Aragón ML, Pontes LF, Bichara LM, Flores-Mir C, Normando D. Validity and reliability of intraoral s compared to conventional gypsum models measurements: a systematic review. Eur J Orthod. 2016;38(4):429-34. doi: 10.1093/ejo/cjw033.

35. Goracci C, Franchi L, Vichi A, Ferrari M. Accuracy, reliability, and efficiency of intraoral scanners for full-arch impressions: a systematic review of the clinical evidence. Eur J Orthod. 2016;38(4):422-428. doi:10.1093/ejo/cjv077. 
36. Ahlholm P,SipiläK, Vallittu P, Jakonen M, Kotiranta U. Digital Versus Conventional Impressions in Fixed Prosthodontics: A Review. J Prosthodont. 2016 Aug 2. doi: 10.1111/jopr.12527.

37. Chochlidakis KM, Papaspyridakos P, Geminiani A, Chen CJ, Feng IJ, Ercoli C. Digital versus conventional impressions for fixed prosthodontics: A systematic review and meta-analysis. J Prosthet Dent. 2016;116(2):184-90.

38. Yang X, Lv P,Liu Y,Si W,Feng H. Accuracy of Digital Impressions and Fitness of Single Crowns Based on Digital Impressions. Materials (Basel).2015 Jun 29;8(7):3945-57.doi:10.3390/ma8073945.

39. Rudolph $\mathrm{H}$, etal. Accuracy of intraoral and extraoral digital data acquisition for dental restorations. J Appl Oral Sci. 2016 Jan-Feb;24(1):85-94. doi: 10.1590/1678-775720150266.

40. Lee JJ, Jeong ID, Park JY, Jeon JH, Kim JH, Kim WC. Accuracy of singlepilares digital cast obtained using intraoral and cast s. JProsthet Dent. 2017 Feb;117(2):253-9. doi:10.1016/j.jposdent.2016.07.021.

41. Ender A, Attin T,Mehl A. In vivo precision of conventional and digital methods of obtaining complete-arch dental impressions. J Prosthet Dent. 2016 Mar;115(3):313-20. doi: 10.1016/.jprosdent.2015.09.011.

42. Ender A,Zimmermann M, Attin T,Mehl A. In vivo precision of conventional and digital methods for obtaining quadrant dental impressions. Clin Oral Investig. 2016 Sep;20(7):1495-504. doi:10.1007/s00784-015-1641-y.

43. Jeong ID, Lee JJ, Jeon JH, Kim JH, Kim HY, Kim WC. Accuracy of completearch model using an intraoral video : An in vitro study.J ProsthetDent. 2016 Jun;115(6):755-9. doi:10.1016/j.prosdent2015.11.007.
44. Carbajal Mejia JB, Wakabayashi K, Nakamura T, Yatani H. Influence of pilares tooth geometry on the accuracy of conventional and digital methods of obtaining dental impressions. J Prosthet Dent. 2017 Sep;118(3):392-9. doi: 10.1016/.jprosdent2016.10.021.

45. LeeSJ, Gallucci GO. Digital vs. conventional implant impressions: efficiency outcomes. Clin Oral Implants Res. 2013 Jan;24(1):111-5. doi: 10.1111//.16000501.2012.02430.x.

46. Seelbach P,Brueckel C, Wöstmann B. Accuracy of digital and conventional impression techniques and workflow. Clin Oral Investig.2013 Sep;17(7):175964. doi:10.1007/s00784-012-0864-4.

47. Cho SH, Schaefer 0, Thompson GA, Guentsch A. Comparison of accuracy and reproducibility of casts made by digital and conventional methods. J Prosthet Dent. 2015 Apr;113(4):310-5. doi:10.1016/j.prosdent.2014.09.027.

48. Ali A0. Accuracy of digital impressions achieved from five different digital impression systems. Dentistry. 2015;5(5):1-6. doi:10.4172/2161-1122.1000300.

49. Mehl A, Ender A, Mörmann W, Attin T. Accuracy testing of a new intraoral 3D camera. Int J ComputDent. 2009;12(1):11-28.

50. Medina-Sotomayor P,Pascual-Moscardó A, Camps I. Correction: Accuracy of four digital scanners according to scanning strategy in complete-arch impressions. PLoS One.2018 Dec 20;13(12). doi: 10.1371/journal.pone.0209883.

Diogo Miguel da Costa Cabecinha Pacheco Viegas

(Corresponding address)

Phone: +351 012038286

Date submitted: 2020 Apr 27

E-mail: diogo.pviegas@gmail.com 